\title{
Pembuatan Kompos Ampas Tebu Dengan Bioaktivator Mol Rebung Bambu
}

\author{
F. Silvi Dwi Mentari* \\ Prodi Budidaya Tanaman Perkebunan \\ Politani Samarinda \\ Samarinda, 75131 \\ dwimentarisilvi@gmail.com \\ *Corresponding author
}

\author{
Yuanita \\ Prodi Budidaya Tanaman Perkebunan \\ Politani Samarinda \\ Samarinda, 75131 \\ yuanita.dethe@ymail.com
}

\author{
Roby \\ Prodi Budidaya Tanaman Perkebunan \\ Politani Samarinda \\ Samarinda, 75131 \\ Robybtp1@gmail.com
}

\begin{abstract}
Abstrak - Penelitian ini bertujuan memperoleh kompos yang memenuhi syarat untuk digunakan sebagai pupuk organik dalam waktu yang tidak terlalu lama. Penelitian ini menjadikan limbah berupa ampas tebu sebagai bahan baku utamanya. Pembuatan kompos dilakukan menggunakan perlakuan mencampur ampas tebu dengan bioaktivator mikro organisme lokal dari rebung bambu yang terlebih dahulu diolah dengan mencampurkan bahan-bahan rebung bambu, gula merah dan air beras untuk selanjutnya difermentasikan sehingga terbentuk MOL yang siap untuk diaplikasikan pada bahan dasar yang akan diolah menjadi kompos. Hasil penelitian menunjukkan bahwa setelah didekomposisi selama 27 hari, kompos berbahan dasar ampas tebu mempunyai kandungan unsur hara $\mathrm{N} 0,3 \%, \mathrm{P} 0,15 \%, \mathrm{~K} 0,53 \%$, KA $13,21 \%$, nisbah $\mathrm{C} / \mathrm{N} 20,45, \mathrm{BO} 34,54 \%$ serta $\mathrm{pH} 6,6$ yang menunjukkan kompos telah matang dan siap digunakan.
\end{abstract}

Kata kunci- Ampas Tebu, MOL, Rebung Bambu, Kompos

\section{PENDAHULUAN}

Dalam pertanian modern saat ini, penggunaan pupuk kimia mulai ditekan, bahkan hampir ditiadakan dan digantikan dengan pupuk organik. Hal ini disebabkan pupuk organik tidak meninggalkan residu kimia, dimana salah satu pupuk organik ialah kompos. Pupuk kompos bukanlah hal yang baru lagi bagi para petani. Nenek moyang kita sudah mengenalnya sejak berabad-abad silam, para leluhur kita sudah melakukan hal tersebut kurang lebih sama dengan praktek pengomposan modern.

Saat ini pemanfaatan limbah sebagai bahan baku kompos lebih diutamakan. Limbah adalah suatu bahan yang terbuang atau dibuang dari suatu sumber aktifitas manusia atau proses-proses alam, dan tidak atau belum mempunyai nilai ekonomi bahkan dapat memiliki nilai ekonomi yang negatif dan positif. Menurut Santoso (2012) limbah dikatakan memiliki nilai negatif dan positif. Dampak yang dapat ditimbulkan limbah adalah berupa dampak negatif seperti gangguan terhadap kesehatan manusia. Gangguan terhadap manusia dapat disebabkan oleh kandungan bakteri, virus, senyawa nitrat, beberapa bahan kimia dari industri dan jenis pestisida yang terdapat dari rantai makanan, serta beberapa kandungan logam seperti merkul, timbal dan kadium. Selanjutnya limbah memiliki dampak negatif gangguan terhadap keseimbangan ekosistem. Kerusakan terhadap tanaman dan binatang yang hidup pada perairan disebabkan oleh eutrofikasi yaitu pencemaran air yang disebabkan oleh munculnya nutrien yang berlebihan ke dalam ekosistem air. Adapula dampak negatif berupa gangguan terhadap estetika dan benda. Gangguan kenyamanan dan estetika berupa warna, bau, dan rasa. Kerusakan benda yang disebabkan oleh garam-garam terlarut seperti korosif atau karat, air berlumpur, menyebabkan menurunnya kualitas tempat-tempat rekreasi dan perumahan akibat bau serta eutrofikasi. Limbah juga dapat mengakibatkan pencemaran bau, di mana limbah organik memiliki bau menyengat. Ini karena adanya unsur nitrogen dan senyawa ammonia di limbah ini.Karena itu, limbah organik harus ditempatkan pada lokasi pengolahan khusus. Dampak lainnya, limbah menyebabkan pertumbuhan berlebihan organisme air. Bila limbah organik masuk ke perairan secara berlebihan, akan mengakibatkan pertumbuhan mikroorganisme air. Pertumbuhan ini diakibatkan kandungan zat organik di limbah ini. Pertumbuhan berlebihan dapat menyebabkan tertutupnya perairan oleh mikroorganisme dan mengganggu kehidupan makhluk hidup di air.

Dampak positif dari adanya limbah yaitu dapat digunakan sebagai pupuk. Limbah organik dapat digunakan sebagai pupuk untuk menyuburkan tanah dengan dijadikan kompos. Kompos mengandung zat organik yang bermanfaat bagi tanaman, sepeti nitrogen dan karbon. Kompos lebih murah dari pada pupuk buatan dan lebih alami. Limbah organik bersifat mudah terurai. Limbah organik tersusun dari senyawa organik yang dihasilkan oleh tanaman dan hewan. Senyawa ini lebih mudah terurai dari pada limbah anorganik seperti plastik. Penguraian ini terjadi akibat aktivitas organisme di dalam tanah seperti cacing dan bakteri. Karena mudah terurai, limbah organik tidak menyebabkan kerusakan tanah.

Tebu (Saccharum officinarum) adalah tanaman yang ditanam untuk bahan baku gula. Tanaman ini hanya dapat tumbuh di daerah beriklim tropis. Tanaman ini termasuk jenis rumput-rumputan. Umur tanaman sejak ditanam sampai bisa dipanen mencapai kurang lebih satu tahun. Di Indonesia tebu banyak dibudidayakan di pulau Jawa dan Sumatra. Ampas tebu merupakan limbah padat produk stasiun gilingan pabrik gula, diproduksi dalam jumlah $32 \%$ tebu yang digiling. Ampas tebu semula banyak dimanfaatkan oleh pabrik kertas, namun karena 
tuntutan dari kualitas kertas dan sudah banyak tersedia bahan baku kertas lain yang lebih berkualitas, sehingga pabrik kertas mulai jarang menggunakannya. Ampas tebu juga dapat dikatakan sebagai produk pendamping, karena ampas tebu sebagian besar dipakai langsung oleh pabrik gula sebagai bahan bakar ketel untuk memproduksi energi keperluan proses, yaitu sekitar 10,2 juta ton per tahun $(97,4 \%$ produksi ampas). Sisanya (sekitar 0,3 juta ton per tahun) terhampar di lahan pabrik sehingga dapat menyebabkan polusi udara, pandangan dan bau yang tidak sedap di sekitar pabrik gula. Ampas tebu mengandung air, gula, serat dan mikroba, ditumpuk akan mengalami fermentasi yang menghasilkan panas. Jika suhu tumpukan mencapai $94^{\circ} \mathrm{C}$ akan terjadi kebakaran spontan (Sutrisno \& Toharisman, 2009). Diperkuat pernyataan Akakusuma et al (2011), bahwa ampas tebu merupakan sisa pengambilan nira, umumnya merupakan $31-34 \%$ bagian dari tebu. Komposisinya $50 \%$ yang terdiri dari $47 \%$ bagian berserat dan $3 \%$ sisa-sisa gula dan padatan terlarut lainnya. Ampas tebu yang dihasilkan umumnya dibakar di dalam ketel sebagai pembangkit tenaga uap untuk menggerakkan mesin pabrik gula dan keperluan proses lainnya. Ampas tebu atau lazimnya disebut bagasse, adalah hasil samping dari proses ekstraksi (pemerahan) cairan tebu. Dari satu pabrik dihasilkan ampas tebu sekitar $35-40 \%$ dari berat tebu yang digiling. Berdasarkan data dari Pusat Penelitian Perkebunan Gula Indonesia (P3GI) ampas tebu yang dihasilkan sebanyak $32 \%$ dari berat tebu giling. Sebanyak $60 \%$ dari ampas tebu tersebut dimanfaatkan oleh pabrik gula sebagai bahan bakar, bahan baku untuk kertas, bahan baku industri kanvas rem, industri jamur dan lain-lain. Sisanya diperkirakan sebanyak $40 \%$ dari ampas tebu tersebut belum dimanfaatkan.

Rahimah et al (2015) menyatakan bahwa ampas tebu merupakan bahan buangan yang biasanya dibuang secara open dumping tanpa pengolahan lebih lanjut, sehingga akan menimbulkan gangguan lingkungan dan bau yang tidak sedap. Berdasarkan hal tersebut perlu diterapkan suatu teknologi untuk mengatasi limbah ini, yaitu dengan menggunakan teknologi daur ulang limbah padat menjadi produk kompos yang bernilai guna. Pengomposan dianggap sebagai teknologi berkelanjutan karena bertujuan untuk konservasi lingkungan, keselamatan manusia dan pemberi nilai ekonomi. Pemanfaatan limbah ampas tebu sebagai bahan baku pembuatan kompos merupakan salah satu alternatif untuk meminimalisir terjadinya polusi estetika. Ampas tebu biasa disebut bagase, merupakan limbah yang dihasilkan dari proses pemerahan atau ekstraksi batang tebu. Satu kali proses ekstraksi menghasilkan ampas tebu sekitar $\pm 35-40 \%$ dari berat tebu yang digiling secara keseluruhan.

Berdasarkan pengamatan peneliti, walaupun tidak terdapat pabrik gula di wilayah Samarinda namun mulai banyak pedagang sari tebu yang menghasilkan banyak limbah berupa ampas tebu.Yuanita (2005) menyatakan bahwa di daerah yang penduduknya sangat padat khususnya daerah perkotaan dilihat tingkat konsumsi yang besar ternyata memiliki bahan baku kompos yang cukup besar pula.
Pemanfaatan ampas tebu sebagai bahan organik dapat berpotensi untuk menjadi pupuk kompos yang dapat menggantikan pupuk anorganik dan bermanfaat bagi pertumbuhan tanaman. Perkembangan dalam bidang pertanian dan industri pertanian di indonesia, sering kali menimbulkan peningkatan residu tanaman yang sebagaian besar merupakan produk samping yang mengandung lignoselulosa (Hendritomo, 2011). Menurut Wahono (2017) ampas tebu mengandung abu 3,82\%, Lignin $22,09 \%$, selulosa $37,65 \%$, sari $1,81 \%$, Pentosa $27,97 \%$ dan $\mathrm{SiO}_{2} 3,01 \%$. Limbah ampas tebu memiliki kadar bahan organik sekitar 90\%, memiliki kandungan hara $\mathrm{N} \mathrm{0,30 \% ,} \mathrm{P2O5} \mathrm{0,02 \% ,} \mathrm{K2O} \mathrm{0,14 \% ,} \mathrm{Ca} \mathrm{0,06 \% ,} \mathrm{dan}$ Mg $0.04 \%$ (BPP, 2002). Serat ampas tebu tidak dapat larut dalam air dan sebagian besar terdiri dari selulosa, pentosan, dan lignin. Apabila ampas tebu dibiarkan begitu saja proses dekomposisinya berlangsung sangat lama. Proses pengomposan juga membutuhkan bantuan mikroorganisme untuk mendekomposisi bahan dan mempercepat proses pengomposan.

Pengomposan merupakan upaya penanggulangan sekaligus dapat bermanfaat bagi daur hidup selanjutnya. Dengan bantuan aktivator, waktu pengomposan dapat dipersingkat, menekan biaya, menghilangkan masalah bau tak sedap dan menghasilkan kompos dengan kualitas baik dan memenuhi syarat untuk dipergunakan sebagai pupuk organik. Dalam penggunaannya, kompos juga tidak meninggalkan residu kimia sehingga merupakan salah satu pendukung terwujudnya pertanian organik. Penggunaan bibit pengaya yang terdiri dari beberapa mikroba diantaranya Azotobacter, Trichoderma, Aspergillus, Pseudomonas maupun mikroorganisme lokal (MOL) lainnya akan menghasilkan kompos yang lebih kaya akan unsur hara ( $N, P$ dan $K$ ) sehingga dapat mempengaruhi produktivitas tanaman.

Menurut Purwasasmita (2014) larutan mikroorganisme lokal (MOL) adalah larutan hasil fermentasi yang berbahan dasar dari berbagai sumber daya yang tersedia di sekitar kita. Larutan mikroorganisme lokal (MOL) mengandung unsur hara mikro dan makro dan juga mengandung bakteri yang berpotensi sebagai perombak bahan organik, perangsang pertumbuhan dan sebagai agen pengendali hama dan penyakit tanaman.

Peranan mikroorganisme lokal (MOL) dalam kompos selain sebagai penyuplai nutrisi juga berperan sebagai komponen bioreaktor yang bertugas menjaga proses tumbuh tanaman secara optimal. Fungsi dari bioreaktor sangatlah kompleks, fungsi yang telah teridentifikasi antara lain adalah penyuplai nutrisi melalui mekanisme eksudat, kontrol mikroba sesuai kebutuhan tanaman, bahkan kontrol terhadap penyakit yang dapat menyerang tanaman.

Bioaktivator merupakan hasil fermentasi terbuat dari bahan-bahan organik yang ada di lingkungan seperti rebung bambu, air cucian beras, gula merah. Kandungan bakteri dalam bioaktivator dapat dimanfaatkan sebagai starter pembuatan pupuk organik, pupuk kompos, pupuk hayati, bahkan pestisida organik. Ciri-ciri MOL yang 
sudah siap dipakai adalah lewat bau yang ditimbulkan cairan akan berbau seperti tape.

MOL rebung bambu berfungsi sebagai perangsang pertumbuhan vegetatif tanaman. Yakni pertumbuhan tunas daun, akar dan batang pada tanaman sebelum memasuki masa pembuangan. MOL rebung bambu juga bisa dimanfaatkan sebagai pengurai dalam proses pembuatan pupuk organik. Rebung bambu mengandung berbagai macam vitamin seperti vitamin A, vitamin B6, vitamin $\mathrm{E}$, thiamin, riboflavin, niasin, asam folat dan asam pantotenat. Selain kaya vitamin bambu muda kaya akan mineral yang baik untuk pertumbuhan tanaman termasuk kalsium $(\mathrm{Ca})$, magnesium $(\mathrm{Mg})$, fosfor $(\mathrm{P})$, kalium $(\mathrm{K})$, natrium $(\mathrm{Na})$, seng $(\mathrm{Zn})$, tembaga $(\mathrm{Cu})$, mangan (Mn), selenium (Se), zat besi $(\mathrm{Fe})$.

Adapun tujuan dari penelitian ini adalah :

1. Mengetahui kandungan unsur hara pada kompos yang diolah dari ampas tebu

2. Memanfaatkan ampas tebu menjadi produk berupa kompos berkualitas baik yang berguna bagi masyarakat

Penelitian ini diharapkan dapat memberikan manfaat :

1. Hasil penelitian ini diharapkan dapat meminimalisir limbah ampas tebu dengan cara memanfaatkan ampas tebu sebagai pembuatan kompos yang dibantu dengan bioaktivator MOL Rebung Bambu

2. Memberikan informasi kepada masyarakat luas bahwa limbah ampas tebu dapat dimanfaatkan sebagai bahan baku pembuatan pupuk kompos.

3. Merupakan langkah positif untuk mengantisipasi kelangkaan pupuk, mahalnya harga pupuk dan menghindari adanya pupuk palsu.

4. Melalui pembuatan kompos ini diharapkan dapat menciptakan lapangan kerja baru.

\section{METODOLOGI PENELITIAN}

\section{A. Waktu danTempat}

Waktu yang diperlukan untuk penelitian ini selama 3 bulan, terhitung dari bulan Desember sampai Februari 2018, meliputi kegiatan persiapan bahan dan alat, pembuatan MOL rebung bambu, pelaksanaan pembuatan kompos, pengujian unsur hara kompos dan pembuatan laporan.

Penelitian ini dilakukan di J1. Kapas no.62 Samarinda dan pengujian unsur hara dilakukan di Laboratorium Tanah Politani Samarinda.

B. Bahan dan Peralatan

Bahan yang digunakan dalam penelitian ini adalah ampas tebu, $7 \mathrm{~kg}$ rebung bambu, 101 air cucian beras, 10 $\mathrm{kg}$ gula merah, dedak.

Peralatan yang digunakan berupa parang, sekop, termometer, $\mathrm{pH}$ meter, terpal plastik, bak pengomposan.

C. Prosedur Penelitian

- Pembuatan Bioaktivator MOL Rebung Bambu

Tahap awal yaitu menyiapkan alat dan bahan yang diperlukan seperti rebung bambu sebanyak $7 \mathrm{~kg}$, gula merah $10 \mathrm{~kg}$, air cucian beras $10 \mathrm{l}$, bak dan jerigen. Setelah alat dan bahan sudah disiapkan maka rebung bambu diiris tipis-tipis atau dapat dilakukan dengan cara ditumbuk, lalu memasukan rebung bambu yang telah dihaluskan ke dalam bak, selanjutnya masukan gula merah yang telah dihaluskan dan air cucian beras, menutup rapat bak tersebut menggunakan plastik, kemudian mengaduk hingga tercampur merata, membuka sebentar tiap pagi sekali agar gas dalam bak bisa keluar, setelah MOL jadi kemudian menyaring ampas bambu yang sudah difermentasikan, kemudian memasukan MOL yang telah jadi ke dalam jerigen untuk digunakan pembuatan pupuk.

- Pembuatan Kompos

Adapun pembuatan kompos dari ampas tebu meliputi langkah-langkah sebagai berikut :

1. Bahan baku berupa ampas tebu dicacah dengan parang sehingga halus $( \pm 1 \mathrm{~cm})$.

2. Bahan baku yang sudah dicacah dan dicampur dengan bioaktivator MOL rebung bambu hingga merata dengan kadar air $\pm 60 \%$ (dicirikan dengan bahan terasa basah bila diremas tetapi air tidak menetes) dimasukkan ke dalam kotak pembuatan kompos. Bahan tersebut selanjutnya ditutup rapat dengan terpal.

3. Selama proses dekomposisi berlangsung, temperatur dijaga dengan cara pembalikan secara teratur.

4. Dilakukan pengamatan warna, bau dan tekstur kompos selama proses pengomposan berlangsung dan pengamatan berakhir bila kompos telah matang ditandai dengan warna kompos yang hitam, bau seperti bau tanah, tekstur remah, temperatur normal (sama dengan suhu ruangan), dan volume menyusut hingga sepertiganya.

D. Pengolahan Data

Pengolahan data berupa laporan hasil pengamatan pembuatan kompos meliputi pengamatan visual kompos, serta hasil analisa laboratorium meliputi,kandungan unsur hara Nitrogen, Phospor, Kalium, kadar air, nisbah $\mathrm{C} / \mathrm{N}$, bahan organik serta $\mathrm{pH}$ yang terkandung dalam kompos ampas tebu yang diolah dengan MOL rebung bambu.

\section{A. Hasil}

\section{HASIL DAN PEMBAHASAN}

Pengomposan dilakukan selama 27 hari. Kompos matang ditandai dengan tidak berbau, warna kehitaman, suhu kembali normal, struktur remah (hancur bila diremas). Hasil akhir dan lama pengomposan sangat tergantung pada bahan yang akan dikomposkan. Sifatsifat bahan yang mempengaruhi antara lain : Kandungan hara dan rasio $\mathrm{C} / \mathrm{N}$, ukuran partikel, aerasi, porositas, kelembababan, suhu dan $\mathrm{pH}$ (Isroi, 2008).

Kondisi $\mathrm{pH}$ pada hari ke-1 adalah 5,5 dan terus meningkat perlahan-lahan menjadi 6,6 pada hari ke-27. Suhu awal pada proses pengomposan adalah $28^{\circ} \mathrm{C}$, peningkatan suhu tertinggi pada hari ke-10 dan ke-11 yaitu sebesar $35^{\circ} \mathrm{C}$ dan perlahan-lahan menurun kembali. Pada hari ke-17 suhu sudah menjadi $26^{\circ} \mathrm{C}$ namun ampas tebu yang diproses menjadi kompos belum sepenuhnya menjadi remah. Suhu tetap stabil $\left(26^{\circ} \mathrm{C}\right)$ sampai pada hari ke-27 dan dari hasil pengamatan secara visual ampas tebu yang awalnya berwarna putih telah berubah menjadi remah dan berwarna kehitam-hitaman.

Hasil analisis kompos berbahan baku ampas tebu menunjukkan nilai kandungan unsur hara $\mathrm{N}$ 0,3\%, P 0,15 
$\%$, K 0,53 \%, KA 13,21\%, nisbah C/N 20,45, BO 34,54\% serta $\mathrm{pH}$ 6,6 yang menunjukkan kompos telah matang dan siap digunakan.

Apabila melihat kandungan unsur hara yang didapatkan dari pembuatan kompos ampas tebu ini, penambahan bahan lain (misalnya seperti kotoran ternak) dalam rangka memasok bahan organik sebaiknya dilakukan untuk melengkapi kandungan hara yang kurang memenuhi standar kualitas kompos sekaligus tetap membantu mendayagunakan limbah yang ada.

B. Pembahasan

Dalam proses pengomposan ampas tebu dengan bioaktivator mol rebung bambu diperlukan waktu selama 27 hari. Penambahan dengan mol rebung bambu membuat laju proses dekomposisi lebih cepat karena dalam bioaktivator tersebut terdapat mikroorganisme atau bakteri dekomposer yang tugasnya mendekomposisi bahan kompos. Sesuai pendapat Indriani (2015), jika dalam pengomposan banyak mengandung mikroorganisme dekomposer maka laju penurunan ketebalan kompos lebih cepat karena banyak bahan yang terurai sehingga mengurangi ketebalan kompos dan strategi yang lebih maju adalah dengan memanfaatkan organisme yang dapat mempercepat proses pengomposan.

Pengomposan ini dilakukan selama 27 hari dan secara visual kematangan kompos dapat diketahui antara lain dari :

1. Bau

Kompos yang sudah matang berbau seperti tanah dan harum. Pada awal pengomposan tercium bau tidak sedap. Hal ini diduga terhambatnya aerasi sehingga terjadi proses anaerob yang menghasilkan bau tidak sedap Proses anaerob akan menghasilkan senyawa-senyawa yang berbau tidak sedap seperti asam-asam organik, amonia, dan $\mathrm{H}_{2} \mathrm{~S}$. Aerasi dapat ditingkatkan dengan melakukan pembalikan pada tumpukan kompos. Kompos yang berbau tidak sedap menandakan bahwa kualitas kompos tersebut tidak baik, sedangkan kompos yang berbau tanah menandakan bahwa kompos tersebut kualitasnya baik dan benar-benar matang. Sesuai pendapat Djuarnani \& Setiawan (2012), bahwa karakteristik bokashi yang telah matang yaitu hilangnya bau tak sedap.

2. Warna

Warna kompos yang sudah matang adalah kehitaman. Berdasarkan hasil pengamatan dalam penelitian pembuatan kompos ampas tebu dengan menggunakan MOL rebung bambu, secara visual ampas tebu yang awalnya berwarna putih telah berubah menjadi remah dan berwarna kehitamhitaman Perubahan warna dari coklat tua pada awal pengomposan hingga kehitaman pada akhir pengomposan disebabkan oleh terdekomposisinya bahan organik oleh aktivitas bermacam-macam mikroorganisme. Proses dekomposisi aerob ditunjukkan dengan terjadinya perubahan warna menjadi kehitaman (Sutanto, 2012). Sesuai dengan pendapat Djuarnani \& Setiawan (2012), bahwa karakteristik bokashi yang telah matang yaitu mempunyai warna cokelat tua sampai kehitamhitaman.

3. Suhu

Tinggi rendahnya suhu ternyata merupakan faktor yang sangat berpengaruh terhadap keberhasilan pembuatan kompos. Peningkatan suhu pada umumnya terjadi sejak awal pembuatan pupuk kompos. Peningkatan tersebut dapat berubah-ubah dari suhu $27-50^{\circ} \mathrm{C}$. Selanjutnya mendekati dengan suhu awal pengomposan yang merupakan indikasi bahwa kompos sudah matang. Suhu meningkat pada awal pengomposan $\left(\geq 30^{\circ} \mathrm{C}\right)$ dan akan tetap tinggi selama waktu tertentu. hal ini menunjukkan terjadinya dekomposisi/penguraian bahan organik yang sangat aktif. Mikroba-mikroba di dalam kompos dengan menggunakan oksigen akan menguraikan bahan organik menjadi $\mathrm{CO}_{2}$, uap air dan panas. Setelah sebagian besar bahan telah terurai, maka suhu akan berangsur-angsur mengalami penurunan. Pada saat itu terjadi pematangan kompos, yaitu pembentukan komplek liat humus.

4. $\mathrm{pH}$

Menurut Indriani (2012), $\mathrm{pH}$ yang baik pada kompos antara 6,5 - 7,5 (netral). Pada penelitian ini kisaran $\mathrm{pH}$ selama proses pengomposan mengalami fluktuasi yaitu saat awal 5,5 dan 6,6 pada akhir pengamatan. Pengomposan yang berjalan berhari-hari mempengaruhi perubahan $\mathrm{pH}$ pada bahan organik. $\mathrm{pH}$ awal pupuk organik dimulai agak asam karena terbentuknya asam-asam organik sederhana, kemudian $\mathrm{pH}$ meningkatkan pada inkubasi lebih lanjut akibat terurainya protein dan terjadinya pelepasan amoniak.

\section{Struktur}

Kompos yang telah matang bersifat remah, akan terasa lunak ketika dihancurkan, ketika diremas-remas akan mudah hancur dan terjadi penyusutan volume/bobot kompos seiring dengan kematangan kompos. Menurut Murbandono (2013), kompos yang matang akan mengalami penyusutan. Hal ini disebabkan oleh hancurnya bahan yang tadinya keras menjadi seperti tanah, bila di remas akan hancur sehingga terjadilah penyusutan dan terjadinya penyusutan juga bisa di sebabkan oleh senyawa zat yang hilang dan menguap ke udara

6. Kandungan bahan organik dan nisbah $\mathrm{C} / \mathrm{N}$ kompos

Adanya kandungan bahan organik yang cukup tinggi pada kompos apabila diaplikasikan pada tanah dapat lebih mudah diamati manfaatnya pada perubahan sifat fisik tanah, meliputi: stimulan terhadap granulasi tanah, memperbaiki struktur tanah menjadi lebih remah, menurunkan plastisitas dan kohesi tanah, meningkatkan daya tanah menahan air sehingga drainase tidak berlebihan, kelembaban dan temperatur tanah menjadi stabil, mempengaruhi warna tanah menjadi coklat sampai hitam, menetralisir daya rusak butir-butir hujan, menghambat erosi, dan mengurangi pelindian (pencucian/leaching). Selain dari pada itu, peranan bahan organik terhadap perubahan sifat biologi tanah 
adalah meningkatkan keragaman dan meningkatkan populasi organisme tanah yang dapat hidup dalam tanah (makrobia dan mikrobia tanah).

Nisbah karbon dan nitrogen (nisbah $\mathrm{C} / \mathrm{N}$ ) sangat penting untuk memasok hara yang diperlukan oleh mikroorganisme selama proses pengomposan berlangsung. Karbon diperlukan oleh mikroorganisme sebagai sumber energi dan nitrogen untuk membentuk protein. Apabila ketersediaan karbon berlebihan $(\mathrm{C} / \mathrm{N}>40)$ jumlah nitogen sangat terbatas sehingga merupakan faktor pembatas pertumbuhan mikroorganisme. Proses dekomposisi menjadi terhambat karena kelebihan karbon harus dibakar/dibuang oleh mikroorganisme dalam bentuk $\mathrm{CO}_{2}$. Nisbah $\mathrm{C} / \mathrm{N}$ yang cukup besar juga menunjukkan sebagai bahan yang sukar terdekomposisi. Penggunaan bioaktivator MOL rebung bambu mempunyai kemampuan untuk menghancurkan bahan organik dalam waktu yang singkat. Mikroba ini mengeluarkan enzim penghancur lignin dan selulosa. Dengan hancurnya lignin dan selulosa, kadar karbon akan turun dan kadar nitrogen meningkat sehingga $\mathrm{C} / \mathrm{N}$ menjadi kecil (Indriani, 2015).

Uji kematangan kompos dilakukan dengan uji laboratorium kompos. Salah satu kriteria kematangan kompos adalah nisbah C/N. Menurut Sofian (2014), analisis sifat kimia kompos dengan nilai rasio $\mathrm{C} / \mathrm{N}$ di bawah 30 masih aman bagi tumbuhan. Dengan demikian, kompos hasil penelitian ini yang bernilai nisbah C/N 20,45 masih sesuai untuk digunakan bagi pemupukan tanaman pertanian maupun perkebunan.

7. Unsur Hara Kompos

Hasil analisis kompos berbahan baku ampas tebu menunjukkan nilai kandungan unsur hara $\mathrm{N} 0,3 \%, \mathrm{P}$ $0,15 \%$, dan K 0,53\%. Menurut Djuarnani dan Setiawan (2012), Unsur N merupakan unsur hara di dalam tanah yang sangat berperan bagi pertumbuhan tanaman. Perilaku nitrogen di dalam tanah sulit diperkirakan karena transformasinya sangat kompleks lebih dari $98 \% \mathrm{~N}$ di dalam tanah tidak tersedia untuk tanaman karena terakumulasi dalam bahan organik atau terjerat dalam mineral liat oleh karena itu, bahan organik yang sudah transformasi menjadi pupuk dapat membantu menyediakan $\mathrm{N}$ bagi tanaman. Suplai unsur $\mathrm{N}$ melalui pemupukan lebih diutamakan untuk tanaman karena merupakan unsur yang paling banyak hilang dari lahan setelah dipanen. Unsur P di dalam tanah, penggolongannya dibedakan menjadi $\mathrm{P}$ organik dan $\mathrm{P}$ anorganik. Ketersediaan $\mathrm{P}$ organik sedikit dibandingkan dengan $\mathrm{P}$ anorganik. Fospor organik berasal dari bahan-bahan organik seperti daun yang telah mengalami deorganiksi dan melepas ion $\mathrm{P}$ sehingga akan masuk ke dalam tanah. Contoh $\mathrm{P}$ organik antara lain fospolipida, asam susinat fitin, dan inositol fospat. Sedangkan P anorganik dalam tanah berkaitan dengan senyawa-senyawa yang sulit larut dalam air seperti Al, Fe, Mn,Ca. Bahan-bahan organik merupakan salah satu faktor penentu ketersediaan hara $\mathrm{P}$ melalui pelapukan yang hasilnya mudah diserap oleh tanaman. Pelapukan tersebut melibatkan mikroorganisme seperti bakteri. Sementara untuk unsur K, secara alami asupan kalium oleh tanaman dapat diperoleh dari tanah, residu seresah bahan organik dan air irigasi. Namun, pada umumnya asupan dari alam tidak selalu tercukupi untuk pertumbuhan dan hasil yang optimal. Dengan demikian tidak diperlukan asupan tambahan dari luar untuk tanaman karena mengandung unsur kalium yang rendah.

Dibandingkan dengan pupuk buatan pabrik, kompos ampas tebu memberikan nilai unsur N, P dan $\mathrm{K}$ yang jauh lebih kecil jumlahnya namun bukanlah sekedar penambahan unsur hara sebagai perbaikan sifat kimia saja yang diperhatikan melainkan dalam jangka panjang juga dapat memperbaiki sifat fisik dan biologi dari tanah.

\section{KESIMPULAN}

Proses dekomposisi ampas tebu sebagai bahan dasar kompos dipercepat dengan tambahan bioaktivator MOL rebung bambu. Pengomposan berlangsung selama 27 hari. Kompos yang dihasilkan telah matang dan siap digunakan. Hasil analisis laboratorium dari sampel kompos berbahan dasar ampas tebu dalam penelitian ini mempunyai kandungan unsur hara $\mathrm{N} 0,3 \%, \mathrm{P} 0,15 \%, \mathrm{~K}$ $0,53 \%$, KA 13,21\%, nisbah C/N 20,45, BO 34,54\% serta pH 6,6.

Dalam rangka mempersingkat kegiatan pengomposan untuk membantu mengatasi permasalahan limbah di perkotaan khususnya ampas tebu sangat dianjurkan untuk menggunakan bioaktivator MOL rebung bambu yang samangat mudah dalam proses pengolahannya. Larutan mikroorganisme lokal (MOL) rebung bambu merupakan larutan hasil fermentasi rebung bambu, gula merah dan air cucian beras yang mengandung unsur hara mikro dan makro dan juga mengandung bakteri yang berpotensi sebagai perombak bahan organik.

Penambahan bahan lain (misalnya seperti kotoran ternak) dalam rangka memasok bahan organik sebaiknya dilakukan untuk melengkapi kandungan hara yang kurang memenuhi standar kualitas kompos sekaligus tetap membantu mendayagunakan limbah yang ada.

\section{DAFTAR PUSTAKA}

Akasuma N., Septu, M. Raiza. 2011. Pembuatan BioEtanol dari Ampas Tebu dengan Variasi Waktu Hidrolisa, Berat Ragi, dan Jenis Ragi.Universitas Sriwijaya Palembang.

Badan Penelitian dan Pengembangan PT. Gula Putih Mataram. 2002. Hasil Analisis Bagase, Blotong, dan Abu. Lampung : PT. Gula Putih Mataram.

Djuarnani, N, dan Setiawan, K.B.S. 2012. Cara Cepat Membuat Kompos. Jakarta: Agromedia Pustaka.

Hendritomo, HI. 2011. Jamur konsumsi berkhasiat obat. Jogjakarta : Penerbit Andi.

Indriani, Y.H. 2015. Membuat Kompos Secara Kilat. Jakarta : Penebar Swadaya. 
Murbandono, L,H,S. 2013. Membuat Kompos. Jakarta : Penebar Swadaya.

Purwasasmita.2014.Pembuatan Larutan Mikroorganisme Lokal. Jakarta : PT Agro Media Pustaka.

Rahimah,M. Mardhiansyah, D. Yoza. 2015. Pemanfaatan Kompos Berbahan Baku Ampas Tebu (saccharum sp.) Dengan Bioaktivator Trichoderma spp. Sebagai Media Tumbuh Semai Acacia crassicarpa. Jom Faperta Vol. 2 No. 1 Februari 2015.

Santoso. 2012. Pemanfaatan Limbah Sebagai Bahan Industri. Jakarta : Kanisus.

Sofian. 2014. Sukses Membuat Kompos dari Sampah. Jakarta : PT Agromedia Pustaka.
Sutanto, R. 2012. Penerapan Pertanian Organik. Yogyakarta : Kanisius.

Sutrisno dan A. Toharisman. 2009. Ikhtisar Angka Perusahaan Tahun Giling 2008 (Inpress). P3GI. Pasuruan-Jatim.

Wahono,T. 2017. Analisis Serat Bagasse. http://eprints.undip.ac.id/58354/4/BAB_II.pdf. diakses tanggal 9 Februari 2021.

Yuanita. 2005. Pembuatan Kompos dari Kulit Buah Pisang (Musa paradisiacal). Buletin Poltanesa Vol.2 Tahun 4, Desember 2005. Samarinda. 